\title{
Phenology (Flowering and Fruiting) of Ten Woody Plants in Linares, North-Eastern Mexico
}

\author{
Humberto Gonzalez Rodriguez ${ }^{1^{*}}$ and Ratikanta Maiti ${ }^{2}$ \\ Universidad Autonoma de Nuevo Leon, Facultad de Ciencias Forestales, Carr. Nac. No 85, km 45, Linares, \\ Nuevo Leon (677 00), Mexico
}

\section{Article History}

Manuscript No. AR1404

Received in $12^{\text {th }}$ July, 2015

Received in revised form $29^{\text {th }}$ July, 2015

Accepted in final form $2^{\text {nd }}$ August, 2015

\section{Correspondence to}

"E-mail: humberto.gonzlez@uanl.mx

\section{Keywords}

Phenology, flowering, fruiting, variability, environment, vegetation

\begin{abstract}
The present study was undertaken to determine flowering and fruiting phenology of 12 woody species in Linares, Northeast of Mexico during the period from March to December 2013. The most representative species are: Prosopis laevigata (Humb. and Bonpl ex Willd.). M.C Johnst, Ebenopsis ebano (Berland.) Barneby and J.W Grimes, Acacia amentacea D.C., Castela erecta Turpin sub sp texana (Torr. and A. Gray) Cronquist, Celtis pallida Torr., Parkinsonia texana var. Macra (IM Johnst.) Isely, Forestiera angustifolia Torr., Cordia boissieri A.DC., Leucophyllum frutescens (Berland.) IM Johnst., Guaiacum angustifolium Engelm., Cylindropuntia leptocaulis (DC.) F.M Knuth, Opuntia spp, Zanthoxylum fagara Sarg., Sideroxylon celastrinum (Kunth) T.D. Penn, Helietta parvifolia (A. Gray ex Hemsl) Benth., among others. The species were selected on the basis of ecological and nutritional value for livestock and wild ruminant animals and multiple uses of shrubs. There exist a large variability in the phenological stages among species. The first study was concentrated on the basis of the percentage of different phenological stages. The second study was mainly concentrated on the time of appearance of each phenological stage in individual species. The results clearly demonstrate about the variation in phenological time schedule among different species. Very little studies have been undertaken in this aspect in the literature. Therefore, there is a need to evaluate the phenology of each individual species. This knowledge will help forest managers for efficient management of the forest as well as the time of seed production of the species of seeds.
\end{abstract}

\section{Introduction}

In a forest exists a great diversity of species which vary in the time of floral initiation, flowering, fruiting and seed dispersal? Different species flower in different times of a year depending on its photoperiod requirements and add a beautiful landscape, galaxy with flowers of different colours at different stages of blooming. A study on the duration of different stages sin a plant such as germination, leaf emergence, the duration of flowering, fruiting, fruit maturity and seed dispersal we called phenology. In a forest one can notice flower of different sizes and colours, very attractive to the pollinators visiting flower in sucking nectar and at the same time help in pollination. I have noticed that the mangrove species produce big white flowers hanging which bloom at night attracting the insects for pollination but in the afternoon many flower petals drop down on the ground indicating quick pollination and competition of fertilization process. We can observe massive viviparous germination which fall on the ground and produce a large number of seedlings. Mangroves are so efficient in fertilization and propagation process.

Phenology determines the different phases of the life cycle of a plant tree ${ }^{-1}$. It can be classified as:

a. Germination and seedling: In this phase, the seeds of a plant germinate in the soil, emerge and grow as seedlings. The seeds of a woody plant possess dormancy which fall on the soil exposed to the edaphic and atmospheric conditions, thereby break dormancy and germinate with the advent of rain showers. The seeds fruits ${ }^{-1}$ of few species are eaten by birds and passed through digestive systems and liberated through excreta, thereby breaking dormancy.

b. Vegetative: The seedlings after germination pass through different phase, finally reach vegetative stage. At this phase, leaves are derived from the meristematic activity of lateral meristem; finally leaves emerge, expand and finally reach to mature stage. Then, the mature leaves undergo the phase of senescence. This phase is called as leaf phenology. It consists of time taken from initiation to final expansion of the leaves. The apical meristem of the shoot at the same time leads to the 
elongation of stem. With the growth of the plant, the intercalary meristem, cambium produces secondary xylem and wood of a timber plant. Before that phase, plant reached reproductive phase. Leaf phenology involves the time of emergence of leaves, their expansion, and senescence.

c. Reproductive phase: This phase determines different stages such as flowering, fruiting and seed dispersal. Apart from other phase mentioned, the reproductive phase is a very important phase related to the productivity of the plant. The photoperiod and temperature determine the initiation of flower bud. Annual plant initiates flowering every year, while the perennial plants take one or more years to initiate flowering. Knowledge on the flowering and seed dispersal is important for efficient management of forest by the forest managers. Various studies have been undertaken on the phenology of trees growing interest has been generated understanding ecological deterioration phenomena and natural restoration of native landscapes has led us to initiate a research effort on a wild species which may be instrumental in the recovery of severely disturbed ecosystems. Chimalacate plants grew almost twice east all, developed twice east many tillers, showed 54\% greater dry weight, $40 \%$ greater leaf expansion rate and over 5 times as many flowers when exposed to full sun as compared to plants growing in the shade. However, shaded plants developed $48 \%$ more leaf area plant ${ }^{-1}$ mainly due to more leaves plant ${ }^{-1}$. Optimum leaf temperature for photosynthesis at highlight intensity and ambient $\mathrm{CO}_{2}$ concentration was $34^{\circ} \mathrm{C}$. Light and $\mathrm{CO}_{2}$ compensation points under a controlled environment ranged between 23 and $48 \mu \mathrm{mol} \mathrm{m}^{-2} \mathrm{~s}^{-1}$ and between 22 and $32 \mu \mathrm{l}^{-1} \mathrm{CO}_{2}$, respectively. The photosynthesis data presented indicates chimalacate is a $\mathrm{C}_{3}$ plant well adapted for growth in a hot dry condition. We undertook two studies on the phenology of different woody species.

\section{Materials and Methods}

\subsection{Study area}

The study has been undertaken during the period from March to December 2013, with 12 species of the Tamaulipas thorn scrub, in an undisturbed area of Nuevo Leon, Mexico. The study site was located at the Experimental Field of the Forest Science School, Universidad Autonomy de Nuevo Leon $\left(24^{\circ} 47^{\prime} \mathrm{N}\right.$, $99^{\circ} 32^{\prime}$ O, 350 masl), $8 \mathrm{~km}$ south of Linares county. The climate is subtropical and semiarid with warm summer. Monthly mean air temperature ranges from $14.7^{\circ} \mathrm{C}$ in January to $22.3{ }^{\circ} \mathrm{C}$ in August, although daily high temperatures of $45^{\circ} \mathrm{C}$ are common during summer. Average total annual precipitation ranges from 600 to $805 \mathrm{~mm}$ with a bimodal distribution. The peak rainfall months are May, June and September (Rodriguez et al., 2004). The dominant soils are deep, dark-gray, lime-gray, lime-clay Vertisols, with montmorillonite, which shrink and swell noticeably in response to changes in soil moisture content.

\subsection{Vegetation of the study area}

The main type of vegetation at the study site is characterized by shrubs and semi-trees, with height between 4 to $6 \mathrm{~m}$, perennial mainly with spines, with small leaves and deciduous. The most representative species are: Prosopis laevigata (Humb. and Bonpl ex Willd.). M.C Johnst, Ebenopsis ebano (Berland.) Barneby and J.W Grimes, Acacia amentacea D.C., Castela erecta Turpin subsptexana (Torr. and A. Gray) Cronquist, Celtispallida Torr., Parkinsonia texana var. Macra (IM Johnst.) Isely, Forestiera angustifolia Torr., Cordia boissieri A.DC., Leucophyllum frutescens (Berland.) IM Johnst., Guaiacum angustifolium Engelm., Cylindropuntia leptocaulis (DC.) F.M Knuth, Opuntia spp, Zanthoxylum fagara Sarg., Sideroxylon celastrinum (Kunth) T.D. Penn, Helietta parvifolia (A. Gray ex Hemsl) Benth., among others. The deciduous species lose their leaves in autumn or in the beginning of winter, while the leaf fall of the perennials occurs in a constant manner throughout the year, although the greater leaf abscission occursbetween summer and autumn (Moro, 1992). The floristic structure composition at research site has been previously documented (Gomez et al., 2013) and it is shown in Table 1.

\subsection{Selection of specimens}

The species were selected on the basis of ecological and nutritional value for livestock and wild ruminant animals (Rodriguez et al., 2010; Gomez et al., 2012) and multiple uses of shrubs in north-eastern Mexico (Reid et al., 1990). In the study area, a total of twelve species including trees and shrubs in an undisturbed plot previously defined of $100 \times 100 \mathrm{~m}^{2}$ representative of the native vegetation. Five plants of each species were selected at random within the plot, being tagged noting the species and replication. The scientific name and family of each species is shown in Table 2. Data were taking on a weekly visit basis and were monitored at the study area during 10 months (March to December, 2013).

\subsection{Study on phenology}

The phenology studied phases were flowering and fruiting. The observations were made at weekly intervals. The flowering include flowers and bud, while the fruiting phenology is considered from the appearance of young fruits (Morellato and Leitao-Filho, 1992). Each phenological phase is studied in terms of percentage, by comparing the branches with the crown of each individual selected. This method is suggested by Fournier (1974) and has one scale of semi-quantitative intervals of four different categories with intervals of $25 \%$ within each one, which allows to estimate the intensity of phenological phase of each individual. The percentage of species in each phenological phase was calculated for evaluating the interspecific synchrony and identifies the porting of species within each phenological phase determined in each phase. This 


\begin{tabular}{lcccccccc}
\hline $\begin{array}{l}\text { Table 1: General characteristics of plant species identified at research site, North Eastern Mexico. A, D, F and IV refer to } \\
\text { abundance, dominace, frequency and importance value, respectively }\end{array}$ & $\begin{array}{c}\text { No. of } \\
\text { Species }\end{array}$ & Phenology & $\begin{array}{c}\text { Height } \\
\text { individuals }\end{array}$ & $\begin{array}{c}\text { Crown cover } \\
(\mathrm{m})\end{array}$ & $\begin{array}{c}\text { A } \\
\left(\mathrm{m}^{2}\right)\end{array}$ & $\begin{array}{c}\text { D } \\
(\%)\end{array}$ & $\begin{array}{c}\text { F } \\
(\%)\end{array}$ & $\begin{array}{c}\text { IV } \\
(\%)\end{array}$ \\
\hline Acacia amentacea & Deciduous & 73 & 2.5 & 142.7 & 6.1 & 6.0 & 5.6 & 17.8 \\
Acacia farnesiana & Deciduous & 4 & 6.3 & 86.1 & 0.3 & 3.6 & 1.6 & 5.7 \\
Acacia schaffneri & Deciduous & 11 & 2.5 & 61.8 & 0.9 & 2.6 & 2.8 & 6.3 \\
Castela erecta & Deciduous & 23 & 1.5 & 16.6 & 1.9 & 0.7 & 4.5 & 7.1 \\
Celtispallida & Deciduous & 28 & 3.4 & 149.4 & 2.3 & 6.3 & 5.0 & 13.8 \\
Condaliahookeri & Perennial & 36 & 2.7 & 131.0 & 3.0 & 5.5 & 2.2 & 10.8 \\
Cordia boissieri & Deciduous & 19 & 3.1 & 127.5 & 1.5 & 5.4 & 3.3 & 10.4 \\
Diospyros texana & Perennial & 34 & 2.7 & 123.3 & 2.8 & 5.2 & 0.5 & 8.6 \\
Eysenhardtia texana & Deciduous & 33 & 3.5 & 183.2 & 2.7 & 7.8 & 5.6 & 16.2 \\
Forestiera angustifolia & Deciduous & 19 & 1.8 & 37.4 & 1.5 & 1.5 & 4.5 & 7.7 \\
Havardiapallens & Deciduous & 40 & 3.1 & 124.6 & 3.3 & 5.3 & 1.1 & 9.8 \\
Lantana macropoda & Deciduous & 230 & 0.9 & 94.3 & 19.2 & 4.0 & 4.5 & 27.8 \\
Leucophylium frutescens & Perennial & 32 & 1.5 & 41.4 & 2.6 & 1.7 & 3.9 & 8.4 \\
Zanthoxylumfagara & Perennial & 38 & 2.2 & 67.0 & 3.1 & 2.8 & 5.0 & 11.1 \\
\hline
\end{tabular}

Table 2: Native species selected for the monitoring of phenological phases

\begin{tabular}{|c|c|c|c|}
\hline Scientific name & Familiy & Type & $\begin{array}{c}\text { Growth } \\
\text { habit }\end{array}$ \\
\hline $\begin{array}{l}\text { Bumelia celastrina } \\
\text { Kunth. }\end{array}$ & Sapotaceae & Tree & Perennial \\
\hline Zanthoxylum fagara Sarg. & Rutaceae & Shrub & Perennial \\
\hline Diospyros texana Sheele & Ebenaceae & Tree & Desidous \\
\hline $\begin{array}{l}\text { Forestiera angustifoli } \\
\text { Torr. }\end{array}$ & Oleaceae & Shrub & Desidous \\
\hline $\begin{array}{l}\text { Prosopis laevigata M.C } \\
\text { Johnst. }\end{array}$ & Fabaceae & Tree & Desidous \\
\hline Parkinsonia texana Torr. & Fabaceae & Tree & Desidous \\
\hline Acacia berlandier Benth. & Fabaceae & Shrub & Desidous \\
\hline Acacia rigidula Benth. & Fabaceae & Tree & Desidous \\
\hline Lantana macropoda Torr. & $\begin{array}{l}\text { Verben- } \\
\text { aceae }\end{array}$ & Tree & Perennial \\
\hline $\begin{array}{l}\text { Leucophyllum frutescens } \\
\text { I.M Johnst. }\end{array}$ & $\begin{array}{l}\text { Scrophula- } \\
\text { riaceae }\end{array}$ & Shrub & Desidous \\
\hline Acacia farnesiana Willd. & Fabaceae & Tree & Desidous \\
\hline $\begin{array}{l}\text { Dichondraar- } \\
\text { genteaWilld. }\end{array}$ & $\begin{array}{l}\text { Convolvu- } \\
\text { laceae }\end{array}$ & Tree & Perenniial \\
\hline
\end{tabular}

variable is utilized mostly on phenological phases, which allows comparison with other studies (Bencke and Morellato, 2002). On the other hand, the percentage of the individuals of each species in each phenological phase allows the evaluation of interspecific synchrony as suggested by Bencke and Morellato (2002). The percentage of Fournier is a variable for which the phenological peaks may be with greater precision and refined, and represents better the phenologic response of each species. In this way, our study on the vegetative and reproductive phenology is shown in terms of species percentage, followed with respect to individuals and finally Fournier's percentage is provided.

\subsection{Environmental variables}

Air temperature $\left(8^{\circ} \mathrm{C}\right)$ and relative humidity (percentage) were registered on a daily basis using a HOBO Pro Data Logger (HOBO Pro Temp/RH Series, Forestry Suppliers, Inc., Jackson, MS, USA). Daily precipitation ( $\mathrm{mm}$ ) was obtained from a Tipping Bucket Rain Gauge (Forestry Suppliers, Inc.). Figure 1 illustrates monthly mean air temperature, monthly mean relative humidity and cumulative monthly rainfall at research site.

\section{Results and Discussion}

The species were selected on the basis of major economic importance included in this study are shrubs and trees belonging to nine families viz., Sapotaceae, Rutaceace, Ebenaceae, Oleaceae, Fabaceae, Verbenaceae, Scrophulariace, and Convulvulaceace. The phenological stages (flowering and fruiting) are graphically represented in Figure 2.

The durations of the flowering and fruiting phases varied widely among species. We describe here the phenological phases of each species. 


\subsection{Bumelia celastrina}

Showed variation in percentage of flowering in different months, such as March $(<50 \%)$, but during the period from April to August did not produce flowers. The plant again started flowering from September to December (but less than 50\%). On the other hand, similarly it showed variation in fruiting percentage such as less than $50 \%$ fruiting occurred during the period from March to June. In the months of October and December less than $50 \%$ fruiting occurred, but in November it produced more than $50 \%$ fruiting.

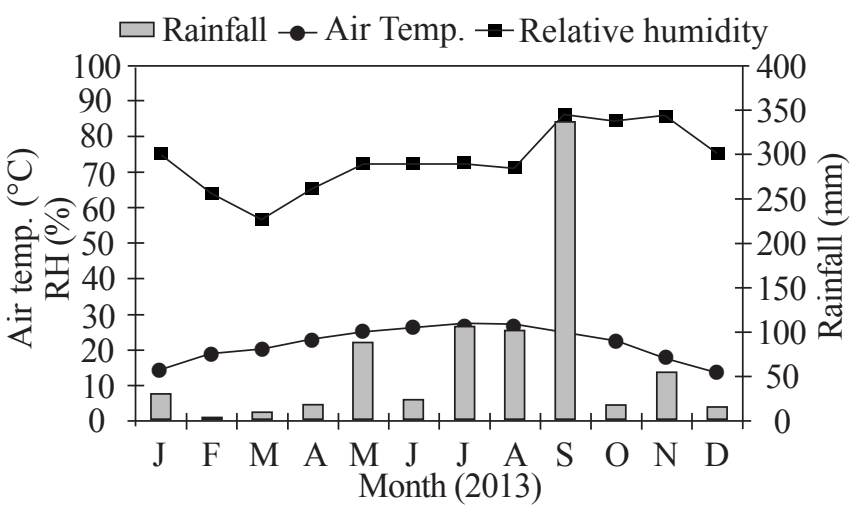

Figure 1: Monthly mean air temperature $\left({ }^{\circ} \mathrm{C}\right)$, monthly mean relative humidity (\%) and monthly rainfall during 2013 at the research site

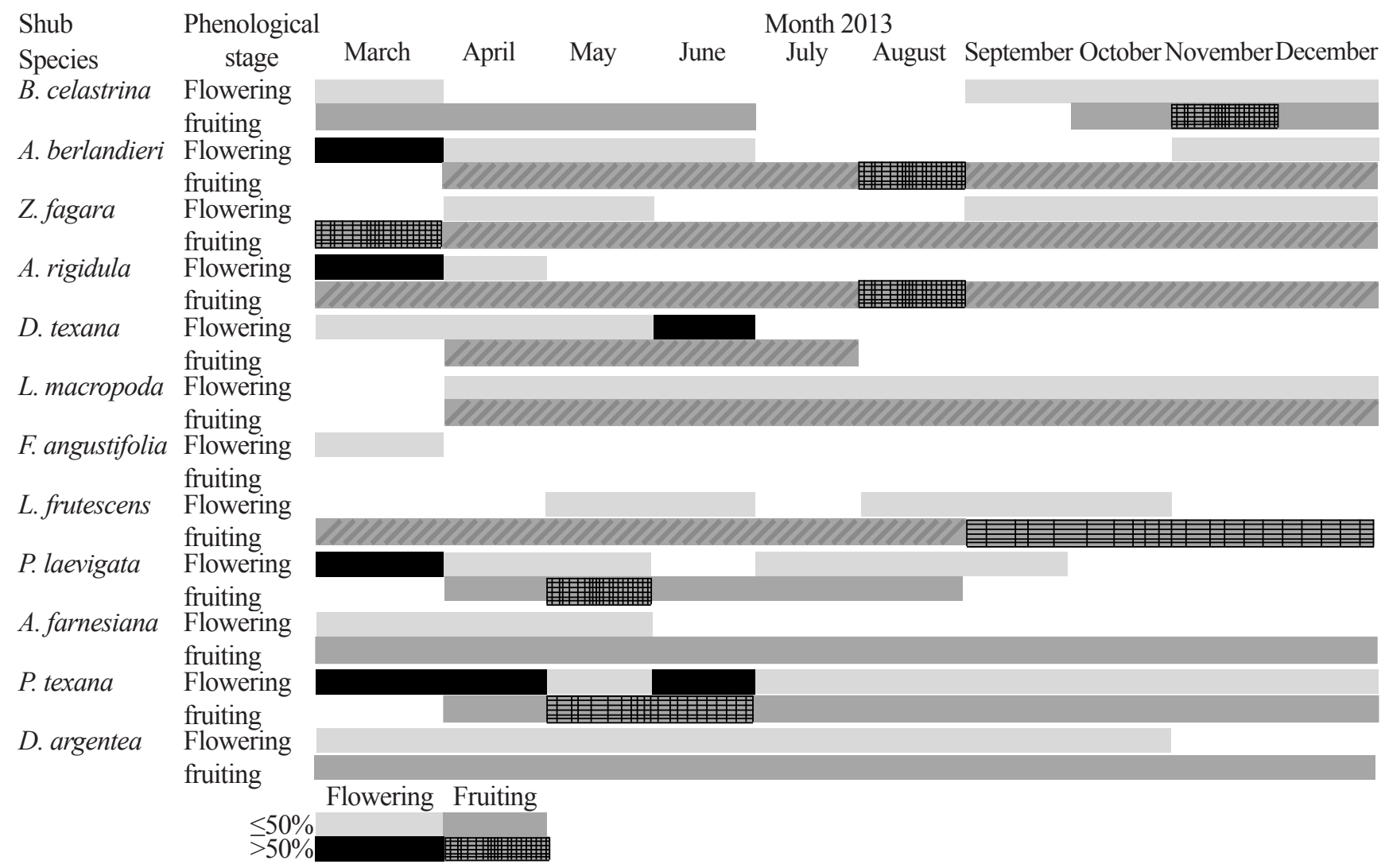

Figure 2: Flowering and fruiting phases in shrubs and tree species between March and December 2013, North-Eastern Mexico

\subsection{Acacia berlandieri}

Produced more than 50\% flowering in March, but it produced less than 50\% from April to June and from November to December. From July to October it did not produce flowers. With respect to fruit phenology, it produced less than $50 \%$ fruiting from April to July, but in August it produced more than $50 \%$, but produced less than $50 \%$ again from September to December.

\subsection{Zanthoxylum fagara}

Produced less than 50\% from April to May, then again from September to December less than 50\% flowering. On the other hand, fruiting phenology attained more than 50\% in March, subsequently from April to December it produced less than $50 \%$ fruiting.

\subsection{Acacia rigidula}

The plant varied in flowering percentage in different months; in March more than 50\% while in April less than 50\%. The rest of the year it did not produce flowers. The plant produced less than $50 \%$ fruiting from March to December with an exception of more than $50 \%$ in August.

\subsection{Diospyrus texana}

The species kept the flowering phase with less than 50\% from Month 2013 
March to May, then more than $50 \%$ in June. With respect to the fruiting phase, from April to July it remains with less than $50 \%$ in the fruiting phase.

\subsection{Lantana macropoda}

This species keeps flowering and fruiting from April continuously up to December with less than $50 \%$.

\subsection{Forestiera angustifolia}

The plant produced flowering less than $50 \%$ in March, but during the rest of the year it did not produce flowers. Data on fruiting was not available.

\subsection{Leucophyllum frutescens}

The plant produced less than 50\% from May to June, it again from August to October it produced less than 50\% flowering. The plant produced more than $50 \%$ fruiting from September to December.

\subsection{Prosopis laevigata}

The plant produced more than 50\% during in March, but it attained less than $50 \%$ from April to May, and the same percentage from July to September. The plant produced less than $50 \%$ fruiting during April to August, but only more than $50 \%$ in May.

\subsection{Acacia farnesiana}

The plant attained more than 50\% from March to May. It produced less than $50 \%$ fruits from March to December.

\subsection{Parkinsonia texana}

It produced more than 50\% flowering from March to April, but it produced different percentage: in May less than $50 \%$, in June more than 50\%), and from July to December less than $50 \%$. It produced fruiting less than $50 \%$ in April, 50\% May to June (more than $50 \%$ ), then from July to December less than $50 \%$.

\subsection{Dichondra argentea}

Flowering less than 50\% from March to October. Similarly, it produced less than $50 \%$ fruits from March to December.

The phenological stages of 12 species during March-October (2014) are shown in the following charts (Figure 3). It is observed that most of the species produce flower bud are two flush, although varying among them in periods (months), for example $A$. rigidula, $Z$. fagara, and $D$. texana (first flush, March to April and the second one from Mid July to October). L. macropoda was in flower bud condition starting from last of April to October. P. laevigata, A. farnesiana, P. texana, first flush from March to May, second flush from July to September. Similarly most of the species showed two periods varying among species in the duration of the period of months as can be noted in the figure above. In this regard, there was large diversity in the periods of flowering. Some species flower during summer months, but only few from July to October. With respect to fruit initiation stage the species shed variability among them in the period of duration of fruit imitation stage. Few species were in continues fruiting stage starting from March to October (viz., F. angustifolia, B. myricaefolia). Few species were in fruit initiation stage from May to September. The species showed large diversity in the periods of mature fruit stage.

The results of the two studies: a) the flowering and fruiting phenology of 12 woody species from March to December, 2013, and b) the study on the flower bud initiation, flowering, fruit initiation, mature fruiting and seed dispersion phase of 12 species during March to October, 2014 revealed that there exist a large variability in the timings of flowering and fruiting phenology of woody species as well different phenological stages.

An analysis of the flowering sequence reveals that different species have different times of flowering. Some species possess two peaks of flowering, while few others continue flowering from April to December. Few species only during March. Almost all the species start flowering in the month of March. In the case of fruiting almost all the species were in fruiting stage from March to December with few exceptions. There was overlapping between flowering and fruiting of few species. Although great variations occur in timing of phenophases among species.

The second study showed remarkable variation in the initiation of flower buds, flowering stage, fruit initiation, fruit maturity and seed dispersal. The results showed that some species have shown bimodal peaks of flowering but few flower from April to December. Few flower in summer season. The periods of fruiting varied among species. Although few species did not flower in hot summer, climate seem not to have effect on phenoloical event, but the rates may differ which need to be studied in future. Concerted future studies need to be directed on fruit maturity and seed dispersal syndromes of the species and seed dormancy.

In this respect, several studies on flower phenology of trees (Morellato and Leitao-Filho, 1992; Talora and Morellato, 2000; Spina et al., 2001) reported the role of biotic factors, such as pollination and dispersal mode. Unfortunately we did not take into account this aspect. In the present study, it seems that environmental conditions did not influence flowering time which coincides with the findings of De Medeiros et al. (2007) 
Shub Phenological

Acacia rigidula Flowering

Zanthoxylum fagara Flowering

Diospyros texana Flowering

Lantana macropoda Flowering

Forestiera angustifolia Flowering

Bernardia myricaefolia Flowering

Acacia berlandieri Flowering

Sideroxylon celastrinum Flowering

Leucophyllum frutescens Flowering

Acacia farnesiana

Parkinsonia texana

Acacia rigidula

Zanthoxylum fagara

Diospyros texana

Lantana macropoda

Bernardia myricaefolia

Acacia berlandieri

Flowering

Flowering

Fruit initiation

Fruit initiation

Fruit initiation

Fruit initiation

Fruit initiation

Fruit initiation

Fruit initiation

Sideroxylon celastrinum Fruit initiation

Leucophyllum frutescens Fruit initiation

Prosopis laevigata

Acacia farnesiana

Parkinsonia texana

Acacia rigidula

Zanthoxylum fagara

Diospyros texana

Lantana macropoda

Forestiera angustifolia

Bernardia myricaefolia

Acacia berlandieri

Fruit initiation

Fruit initiation

Fruit initiation

Fruit maturity

Fruit maturity

Fruit maturity

Fruit maturity

Fruit maturity

Fruit maturity

Fruit maturity

Sideroxylon celastrinum Fruit maturity

Leucophyllum frutescens Fruit maturity

Prosopis laevigata

Acacia farnesiana

Fruit maturity

Fruit maturity

Acacia rigidula

Zanthoxylum fagara

Diospyros texana

Lantana macropoda

Forestiera angustifolia

Bernardia myricaefolia

Acacia berlandieri

Seed dispersal

Seed dispersal

Seed dispersal

Seed dispersal

Seed dispersal

Seed dispersal

Seed dispersal

Leucophyllum frutescens Seed dispersal

Prosopis laevigata

Acacia farnesiana

Parkinsonia texana

Acacia rigidula

Zanthoxylum fagara

Diospyros texana

Lantana macropoda

Forestiera angustifolia

Bernardia myricaefolia

Acacia berlandieri

Seed dispersal

Seed dispersal

Seed dispersal

Flower bud

Flower bud

Flower bud

Flower bud

Flower bud

Flower bud

Flower bud

Sideroxylon celastrinum Flower bud

Leucophyllum frutescens Flower bud

Acacia farnesiana

Parkinsonia texana

Flower bud

Flower bud Species Stage

Prosopis laevigata Flowering

Forestiera angustifolia

Fruit maturity

Sideroxylon celastrinum Seed dispersal

Prosopis laevigata Flower bud

Month 2014

March April May June July August September October November December
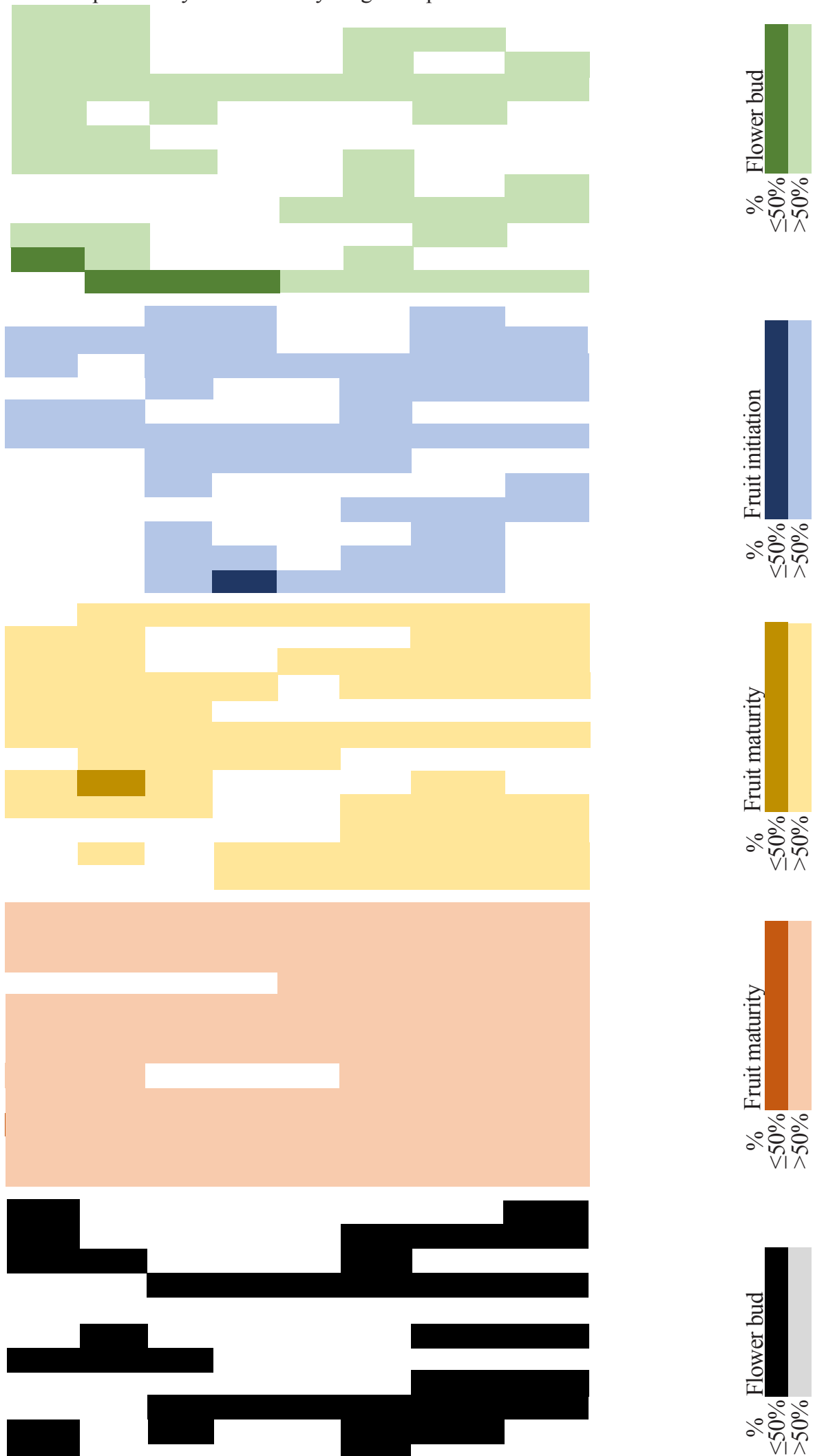

Figure 3: Phenological stages of 12 species during March-October (2014) 
in coastal vegetation of Brazil. In the present study, during hottest months few species did not flower which may be due to low viability of pollen and low perceptibility of stigma in the prevailing high temperature during this period. On the other hand, some researchers reported in different ecosystems that the flowering time is influenced by several factors such climatic variation (Debussche et al., 2004), soil moisture (Struck, 1994), the availabity of pollinators (Waser, 1979; Johnson and Bond, 1994; Johnson, 1992; Dreyer and Makgakga, 2003). On the other hand, excellent studies were undertaken on the phenology of different woody species in different countries. In this respect, Krishnan (2004) in a study on the reproductive phenology of endemic species in a wet forest of the Western Ghats, south India, reported that the peak flowering was observed during the dry and post-monsoon seasons for the endemic species, while the non-endemic species flowered during the dry season. Zhang et al. (2014) reported in China that low temperature reduce the activity of pollinators in figs owing to which very few figs flower in winter seasons. Similarly, Salinas-Peba and Parra-Tabla (2007) working on the phenology and pollination of Manilkara zapota in forest in Yucatan, Mexico, reported significant differences between environments both in the temporal distribution of flower and mature fruit production, as well as in the proportion of mature fruits. In present study, fruiting showed more or less similar pattern, although no synchrony was found between flowering and fruiting of few species showing lack of relation with rainfall. Besides, at the study site, from March to August prevailed drought with insignificant rains, but it received high rainfall only in September followed by drought period up to December but the presence of drought did not show any significant effect on phenology, although showing variations among species. We could not study in detail on fruit phenology of the woody species with special reference to seed dispersal syndrome, but several excellent studies have been undertaken on fruit phenology of few tree species in different countries.

Chmielewski et al. (2004) reported the impact of the climate changes on the phenology of fruit trees and field crops in Germany. The late spring phases and summer phases reacted also to the increased temperatures, but they usually show lower trends. An interesting study has been undertaken by Selwyn and Parthasarathy (2007) on the fruiting phenology in a tropical dry evergreen forest on the Coromandel Coast of India and its relation to plant life-forms, physiognomic groups, dispersal modes, and climatic constraints. Although no significant differences were observed in the frequency of species at three fruiting stages across the life-form categories and many species of upper and lower canopy trees, it was reported that the fruit maturation period was much longer for the wet season fruiting brave-deciduous species than evergreen and deciduous species that fruited during the dry season. Fruiting in anemochorous species peaked during the driest months and dryness favoured the dissemination of seeds.

Borges et al. (2009) studied the phenology, pollination, and breeding system of the threatened tree Caesalpinia echinata Lam. (Fabaceae). Caesalpinia echinata (Brazil wood) is a threatened tree endemic to the Brazilian Atlantic forest. Flowering occurred mainly in the dry season and the peak of seed dispersal started at the beginning of the wet season. The effective pollinators were mainly bees of the genera Centris and Xylocopa. Results under the controlled pollinations and analysis of pollen tube growth revealed the predominance of bee pollination and SI system, with the occurrence of lateacting self-incompatibility mechanisms in some species. We could not look in this aspect. Genini et al. (2009) studied the fruiting phenology of palms and trees in an Atlantic rainforest land-bridge island stating an important role in the maintenance of frugivore populations in isolated, disturbed environments with a high density of vertebrate frugivores, low diversity of fruiting species and fruit biomass such as those found on Anchieta Island. Hart et al. (2013) studying the fruiting phenology of the fragmented Ngele Forest Complex, KwaZuluNatal, assessed that fruiting in three of the forest fragments did not show seasonal fruiting trends and had increased fruiting in late summer and autumn months. Fruiting varied significantly between months for all fragments, and where annual variation was observed trends were insignificant.

Cortes-Flores et al. (2013) working on the fruiting phenology of 133 plant species in a Mexican sub-humid temperate forest located in the tropical zone recorded the presence/absence of ripe fruits was monthly for each plant species. They classified each species according to its main seed dispersal syndrome (anemochorous, autochorous, zoochorous) and its growth form (tree, shrub, herb). Zoochory was most prominent among tree species. Shrubs showed uniform distribution of the syndromes. The three dispersal syndromes showed a negative correlation between precipitation and the number of species fruiting. The autochorous and zoochorous species also showed inverse relationships with temperature. The results suggest a complex relationship between fruiting phenology and dispersal syndromes with abiotic (precipitation and temperature) and biotic factors (growth form and seed dispersal) in the forest studied.

\section{Conclusion}

There exist a large variability in the phenological stages among species. The first study was concentrated on the basis of the percentage of different phenological stages. The second 
study was mainly concentrated on the time of appearance of each phenological stages in individual species. This gives clear cut information about the phenological time schedule of each species. Very little attempt has been undertaken in this aspect in the literature. Therefore, concerted reach inputs need to be directed to evaluate the phenology of each individual species. This knowledge will help forest managers for efficient management of the forest.

\section{References}

Bencke, C.S.C., Morellato, L.P.C., 2002. Estudo comparativo da fenologia de nove especies arboreas emtrês tipos de Floresta Atlantica no Sudeste do Brasil. Revista Brasileira de Botanica 2, 237-248.

Borges, L.A., Sobrinho, M.S., Lopes, A.V., 2009. Phenology, pollination, and breeding system of the threatened tree Caesalpinia echinata Lam. (Fabaceae), and a review of studies on the reproductive biology in the genus. FloraMorphology, Distribution, Functional Ecology of Plants 204(2), 111-130.

Chmielewski, F.M., Müller, A., Bruns, E., 2004. Climate changes and trends in phenology of fruit trees and field crops in Germany, 1961-2000. Agricultural and Forest Meteorology 121(1-2), 69-78.

Cortes-Flores, J., Andresen, E., Cornejo-Tenorio, G., IbarraManriquez, G., 2013. Fruiting phenology of seed dispersal syndromes in a Mexican Neotropical temperate forest. Forest Ecology and Management 289, 445-454.

De Medeiros, D.P.W., Lopes, A.V., Zickel, C.S., 2007. Phenology of woody species in tropical coastal vegetation, northeastern Brazil. Flora-Morphology, Distribution, Functional Ecology of Plants 202(7), 513-520.

Debussche, M., Garnier E., Thompson, J.D., 2004 Exploring the causes of variation in phenology and morphology in Mediterranean geophytes: a genus-wide study of Cyclamen. Botanical Journal of the Linnean Society 145(4), 469-484.

Gomez, T.G.D., Rodriguez, H.G., Ramirez Lozano, R.G., Estrada Castillon, A.E., Cantu Silva, I., Gomez Meza, M.V., Villarreal Quintanilla, J.A., Alvarado, M.S., Alanis Flores, G., 2013. Diversidad estructural del matorral espinoso tamaulipeco durante las epocas seca y humeda. Revista Mexicana de Ciencias Forestales 4(17), 106-123.

Gomez, T.G.D., Ramirez Lozano, R.G., Estrada Castillon, A.E., Scott Morales, L.M., Rodriguez, H.G., Alvarado, M., del, S., 2012. Importancia nutrimental en plantas forrajeras del matorral espinoso tamaulipeco. Ciencia
UANL 15(59), 77-93.

Dreyer, L.L., Makgakga, M.C., 2003. Oxalidaceae. In: Germishuizen, G., Meyer, N.L. (Eds.), Plants of Southern Africa: An Annotated Checklist, Strelitzia, vol. 14. National Botanical Institute, Pretoria, 174-194.

Fournier, L.A., 1974. Un metodo cuantitativo para la medicion de caracteristicas fenologicas en arboles. Turrialba 24, 422-423.

Genini, J., Galetti, M., Morellato, L.P.C., 2009. Fruiting phenology of palms and trees in an Atlantic rainforestlandbridge island. Flora-Morphology, Distribution, Functional Ecology of Plants 204(2), 131-145.

Rodriguez, H.G., Cantu Silva, I., Gomez Meza, M.V., Ramirez Lozano, R.G., 2004. Plant water relations of thornscrub shrub species, north-eastern Mexico. Journal of Arid Environments 58(4), 483-503.

Rodriguez, H.G., Cantu-Silva, I., Ramirez-Lozano, R.G., Gomez-Meza, M.V., Uvalle-Sauceda, J.I., Maiti, R.K., 2010. Characterization of xylem water potential in ten native plants of north-eastern Mexico. International Journal of Bio-resource and Stress Management 1(3), 219-224.

Hart, L.A., Grieve, G.R.H., Downs, C.T., 2013. Fruiting phenology and implications of fruit availability in the fragmented Ngele Forest Complex, KwaZulu-Natal, South Africa. South African Journal of Botany 88, 296305 .

Johnson, S.D., 1992. Plant- animal relationships. In: Cowling, R. (Ed.), The Ecology of Fynbos. Nutrients, Fire and Diversity. Oxford University Press, Cape Town, 175205.

Johnson, S.D., Bond, W.J., 1994. Red flowers and butterfly pollination in the fynbos of South Africa. In: Arianoutsou, M., Groves, R.M. (Eds.), Plant Animal Interactions in Mediterranean-Type Ecosystems. Kluwer Academic Press, Dordrecht, 137-148.

Krishnan, R.M., 2004. Reproductive phenology of endemic understorey assemblage in a wet forest of the Western Ghats, South India. Flora-Morphology, Distribution, Functional Ecology of Plants 199(4), 351-359.

Morellato, L.P.C., Leitao-Filho, H.F., 1992. Padroes de frutificaço e disperso na Serra do Japi. In: Morellato, L.P.C. (Ed.), Historia natural da Serra do Japi: ecologia e preservaçao de uma area florestal no sudeste do Brasil. Editora da Unicamp/Fapesp, Campinas, 112-140.

Moro, M.J., 1992. Desfronde, descomposicion y fijacion de nitrogeno en una microcuenca con repoblacion joven de coniferas y matorral de Cistuslaurifoliusy Adenocarpus 
decorticans en la Sierra de los Filabres (Almeria). Tesis doctoral. Alicante, Espana. Facultad de Ciencias. Universidad de Alicante, 463.

Reid, N., Marroquin, J., Beyer-Münzel, P., 1990. Utilization of shrubs and trees for browse, fuel wood and timber in the Tamaulipan thornscrub, north-eastern Mexico. Forest Ecology and Management 36, 61-79.

Salinas-PebaL, Parra-Tabla, V., 2007. Phenology and pollination of Manilkara zapota in forest and homegardens. Forest Ecology and Management 248(3), 136-142.

Selwyn, M.A., Parthasarathy, N., 2007. Fruiting phenology in a tropical dry evergreen forest on the Coromandel coast of India in relation to plant life-forms, physiognomic groups, dispersal modes, and climatic constraints. Flora - Morphology, Distribution, Functional Ecology of Plants 202(5), 371-382.

Spina, A.P., Ferreira, W.M., Leitao-Filho, H.F., 2001. Floracao e sindromes de dispersao de umacomunidade de floresta de brejo na regiao de Campinas (SP). Acta Botanica Brasilica 15, 349-368.

Struck, M., 1994. Flowering phenology in the arid winter rainfall region of southern Africa. Bothalia 24(1), 7790.

Talora, D.C., Morellato, P.C., 2000. Fenologia de especies arboreas em floresta de planicie litoranea do sudeste do Brasil. Revista Brasileira de Botanica 23, 13-26.

Waser, N.M., 1979. Pollinator availability as a determinant of flowering time in ocotillo (Fouquieria splendens). Oecologia 39, 107-121.

Zhang, L.S., Compton, S.G., Xiao, H., Lu, Q., Chen, Y., 2014. Living on the edge: Fig tree phenology at the northern range limit of monoecious Ficus in China. Acta Oecologica 57, 135-141. 